\title{
WEED CONTROL IN PERILLA
}

\author{
M.J. HARTLEY \\ Lawn Road, R D 2, Hastings
}

\begin{abstract}
Perilla (Perilla frutescans) is an annual herbaceous herb used in Asia as a vegetable and for food flavouring. Trials were conducted over 2 years to test its tolerance to herbicides suitable for weed control. Perilla showed good tolerance to trifluralin, pendimethalin or oxadiazon applied to the soil before transplanting the seedlings but only to bentazone applied over the seedlings. Linuron, metribuzin, chlorpropham, prometryn, oxadiazon and simazine were all tolerated as inter-row treatments applied 6 weeks after transplanting, with oxadiazon and metribuzin giving best weed control.
\end{abstract}

Keywords: perilla, herbicide tolerance, weed control, herbs

\section{INTRODUCTION}

Perilla (Perilla frutescans), a member of the Labiatae family, is an annual herb native to Asia but regarded as a common weed in the Eastern United States (Brenner 1995). There are two main types with either red or green leaves. Green perilla is used in Japan as a vegetable in salads or as a food wrapping (Follett 1995). The red type is used as a vegetable dye or as a dried powder in rice, cakes or beverages. Perilla seed can also be used as a food for humans and birds or as a source of oil for fuel or cooking (Brenner 1993).

Perilla may have a potential as an export crop for New Zealand in which case weed control would be necessary for commercial production. There was no information on herbicide tolerance of perilla so trials were conducted at the Hawkes Bay Research Centre in 1994-95 and 1995-96 to test the tolerance of perilla to certain herbicides.

\section{METHOD}

All trials were conducted on transplanted seedlings, grown by a commercial propagator, and transplanted into field plots, spaced $40 \mathrm{~cm}$ apart in single rows with six plants per plot. In 1994-95 red and green perilla were used but in 1995-96, only green perilla was used. The herbicide treatments were applied by precision sprayer at $210 \mathrm{kPa}$ in 200 litres/ha.

\section{Trial 1}

In 1994, the perilla for post-plant treatments (topical application) was planted on 16.11.94 (green) and 23.11.94 (red). Herbicide treatments (Table 1) were applied postplanting on 24.11.94 and further plantings of perilla (green and red) were made on 25.11.94 into herbicide treated soil (pre-plant treatments). Treatments were replicated three times in randomised blocks.

\section{Trial 2}

In 1995 trifluralin (Triflur 40) was applied as a main treatment to one block on 16.11.95 and incorporated by rotary hoe. Sub-treatments, replicated three times, with and without trifluralin, were, pendimethalin (Stomp 330E) and oxadiazon (Foresite) applied pre-planting on 17.11.95 and bentazone (Basagran) applied topically on 10.1.96. Perilla was planted on 22.11.95.

\section{Trial 3}

Perilla was planted on 13.11 .95 and herbicides were applied on 29.12.95, interrow, allowing the spray to contact the basal $20 \mathrm{~cm}$ of the perilla. There were four replications. 
Perilla vigour was assessed visually at intervals in all trials and plant height measured on 24.1.95 in Trial 1. Fresh weight yield was recorded in all trials by cutting plants $15 \mathrm{~cm}$ above soil level. Yield is expressed per plant in Trial 1 as some losses occurred at transplanting which were not related to herbicide effects. Weeds were counted on the whole plots in Trial 1 and assessed visually in Trials 2 and 3 .

A small additional trial was conducted in 1995 on an area treated with EPTC (Eradicane) at $4.3 \mathrm{~kg} / \mathrm{ha}$. Sixteen seedlings were planted into EPTC treated soil and 16 into an adjacent untreated plot.

\section{Trial 1}

\section{RESULTS}

Both green and red perilla seedlings showed good tolerance to pendimethalin (1 and $2 \mathrm{~kg} / \mathrm{ha}$ ) and oxadiazon (1.6 kg/ha) applied pre-planting but were severely affected by pendimethalin applied over the top after planting (Table 1). Bentazone applied 3 or 4 weeks after planting was well tolerated. Perilla showed poor tolerance to simazine (Gesatop $500 \mathrm{FW}$ ) and no tolerance to terbacil (Sinbar) pre- or post-planting. Best weed control was achieved with the non-tolerated herbicides but oxadiazon, bentazone and the higher rate of pendimethalin pre-planting gave useful weed control.

TABLE 1: Weed number and perilla growth and yields following herbicide treatments applied before and after transplanting green and red perilla in 1994.

\begin{tabular}{|c|c|c|c|c|c|c|c|}
\hline \multirow{2}{*}{$\begin{array}{l}\text { Treatment } \\
\text { applied } \\
24.11 .94\end{array}$} & \multirow{2}{*}{\multicolumn{2}{|c|}{$\begin{array}{l}\text { Rate } \\
\mathrm{kg} \text { ai/ha }\end{array}$}} & \multirow[t]{2}{*}{$\begin{array}{c}\text { No. weed/m } \\
10.1 .95^{1}\end{array}$} & \multicolumn{2}{|c|}{$\begin{array}{c}\text { Perilla height }(\mathrm{cm}) \\
24.1 .95\end{array}$} & \multicolumn{2}{|c|}{$\begin{array}{c}\text { Perilla FW (g/plant) } \\
10.2 .95\end{array}$} \\
\hline & & & & Green & Red & Green & Red \\
\hline untreated & & & $36^{2}$ & 48 & 41 & 670 & 360 \\
\hline pendimethalin & & pre $^{3}$ & 94 & 49 & 43 & 570 & 350 \\
\hline pendimethalin & 2 & pre & 47 & 48 & 40 & 560 & 320 \\
\hline pendimethalin & 1 & post $^{3}$ & 123 & 19 & 22 & 140 & 110 \\
\hline pendimethalin & 2 & post & 62 & 13 & 12 & 70 & 50 \\
\hline terbacil & 1 & pre & 10 & 0 & 0 & 0 & 0 \\
\hline terbacil & 1 & post & 9 & 0 & 0 & 0 & 0 \\
\hline oxadiazon & 1.6 & 6 pre & 34 & 52 & 42 & 630 & 380 \\
\hline simazine & 3 & post & 12 & 13 & 3 & 300 & 80 \\
\hline bentazone & 2 & later ${ }^{3}$ & 40 & 42 & 39 & 690 & 350 \\
\hline LSD $5 \%$ & & & 29 & 81 & 81 & 97 & 76 \\
\hline
\end{tabular}

${ }^{1}$ Main weeds, black nightshade (Solanum nigrum) and white clover (Trifolium repens)

${ }^{2}$ Hand weeded on 21.12.94.

${ }^{3}$ pre $=$ applied before planting; post $=$ applied 1 (red) or 8 (green) days after planting; bentazone applied 13.12.94.

\section{Trial 2}

Perilla again showed good tolerance to pre-planting applications of pendimethalin and oxadiazon at the higher rates which also gave reasonable early weed control (Table 2). It also showed good tolerance to trifluralin $(1 \mathrm{~kg} / \mathrm{ha})$, although this treatment did not greatly improve early weed control due to the presence of black nightshade.

\section{Trial 3}

All herbicides applied inter-row were well tolerated by established perilla (Table 3 ). Best early weed control was provided by linuron, metribuzin, the chlorpropham/ prometryn combination and oxadiazon, with metribuzin and oxadiazon giving best lasting control.

The 16 seedlings grown in EPTC treated soil showed no visually assessable difference in growth to those in untreated soil 6 weeks after planting but yields were not recorded. 
TABLE 2: Weed growth and perilla vigour and yield following herbicide treatments. Perilla planted 22.11.95.

\begin{tabular}{|c|c|c|c|c|c|}
\hline \multirow{3}{*}{$\begin{array}{l}\text { Treatment applied } \\
\text { 17.11.95 }\end{array}$} & \multirow{3}{*}{$\begin{array}{c}\text { Rate } \\
\text { (kg ai/ha) }\end{array}$} & \multicolumn{2}{|c|}{ Weed score $^{1}$} & \multicolumn{2}{|c|}{ Perilla } \\
\hline & & & & Vigour & Yield $(\mathrm{kg})$ \\
\hline & & 29.12 .94 & 25.3 .95 & 9.1 .96 & 25.3 .95 \\
\hline
\end{tabular}

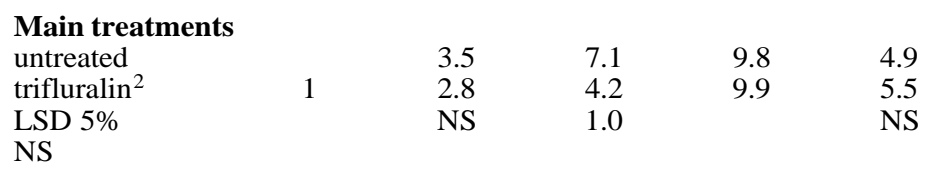

\section{Sub treatments}

$\begin{array}{llrrrr}\text { untreated } & & 3.8 & 7.0 & 10.0 & 3.9 \\ \text { pendimethalin } & 1 & 2.7 & 5.7 & 9.8 & 4.9 \\ \text { pendimethalin } & 2 & 1.8 & 4.8 & 10.0 & 6.5 \\ \text { oxadiazon } & 1 & 3.8 & 6.5 & 9.8 & 4.8 \\ \text { oxadiazon }_{\text {bentazone }^{3}} & 2 & 2.2 & 3.7 & 9.5 & 6.3 \\ \text { LSD 5\% } & 2 & 4.7 & 6.2 & 9.8 & 4.8 \\ \end{array}$

${ }^{1}$ Weed score; $0=$ no weeds, $10=$ complete weed cover

${ }^{2}$ Applied and incorporated on 16.11 .95

3 Applied topically 10.1 .96

TABLE 3: Perilla vigour and yield and visual estimates of weed control following inter-row application of herbicides. Perilla planted 13.11.95.

\begin{tabular}{lccccc}
\hline $\begin{array}{l}\text { Treatment } \\
\text { applied }\end{array}$ & $\begin{array}{c}\text { Rate } \\
\text { 29 ai/ha) }\end{array}$ & \multicolumn{2}{c}{ Weed score $^{1}$} & \multicolumn{2}{c}{ Perilla } \\
& & & & Vigour & Yield(kg) \\
& & 9.1 .96 & 25.3 .96 & 9.1 .96 & 25.3 .96 \\
\hline $\begin{array}{l}\text { untreated } \\
\text { chlorpropham }\end{array}$ & 3 & 3.3 & 5.0 & 9.8 & 7.6 \\
chlorpropham & $1.25+0.75$ & 1.5 & 3.5 & 10.0 & 8.4 \\
$\quad+$ prometryn & & 0.3 & 3.0 & 9.5 & 8.3 \\
linuron & 2 & 0 & 2.3 & 9.0 & 8.0 \\
metribuzin & 0.75 & 0.3 & 1.8 & 9.5 & 8.4 \\
oxadiazon & 2 & 0.4 & 1.3 & 9.5 & 8.6 \\
simazine & 3 & 2.3 & 4.5 & 9.8 & 8.4 \\
LSD 5\% & & 1.9 & 3.6 & NS & NS \\
\hline
\end{tabular}

${ }^{1}$ Weed score; $0=$ no weeds, $10=$ complete weed cover

\section{DISCUSSION}

Though none of these treatments alone gave very good weed control, a number of herbicides were well tolerated by perilla. However, except for bentazone, perilla appears sensitive to treatments applied over the growing plants. The good tolerance to trifluralin suggests this would be a useful treatment. This could be followed by pendimethalin or oxadiazon applied before transplanting but these herbicides did not give season long weed control. However, if perilla is grown as a row crop, several herbicides could be used inter-row as directed sprays, the most effective being linuron, metribuzin and oxadiazon. If grown as a close spaced crop, bentazone could be used as a topical treatment. Perilla is a vigorous plant and if grown closely spaced, it should provide good weed competition once established. There are also indications that 
perilla could be grown in soil pre-treated with EPTC giving a possible alternative to trifluralin as a soil incorporated treatment.

The extreme toxicity of terbacil to perilla was unexpected as terbacil is a useful treatment for several labiate herbs such as oregano, lemon balm, mint and thyme (Hartley 1993). In an unrelated trial, two patches of transplanted perilla showed very severe stress symptoms. Plot mapping showed these two patches coincided with terbacil having been applied 18 months earlier at $1 \mathrm{~kg} / \mathrm{ha}$. The ground had been cultivated twice in the interval before perilla was planted but the effect was still devastating, indicating extreme sensitivity of perilla to terbacil.

\section{ACKNOWLEDGEMENTS}

I would like to acknowledge funding from the N.Z. Institute for Crop \& Food Research Ltd and the use of their land and facilities to conduct this research. I thank Heather Martin for assistance with the trials.

\section{REFERENCES}

Brenner, D.M., 1993. Perilla: Botany, Uses and Genetic Resources. Pp 322-328 In: New Crops. J. Janick and J. E. Simon, (Eds) John Wiley and Sons, Inc. New York. Follett, J.M., 1995. Perilla: Production in Japan and Potential for New Zealand. Combined Proc. Int. Plant Propagation Soc. 45: 78-81.

Hartley, M.J., 1993. Herbicide tolerance and weed control in culinary herbs. Proc. 46th N.Z. Plant Prot. Conf:: 35-39. 